\title{
Planting Date, Seeding Rate, and Cultivar Impact Agronomic Traits and Semolina of Durum Wheat
}

\author{
Shana M. Forster ${ }^{1 *}$, Joel K. Ransom², Frank A. Manthey², John R. Rickertsen ${ }^{3}$, Grant H. Mehring² \\ ${ }^{1}$ North Central Research Extension Center, North Dakota State University, Minot, ND, USA \\ ${ }^{2}$ Department of Plant Sciences, North Dakota State University, Fargo, ND, USA \\ ${ }^{3}$ Hettinger Research Extension Center, North Dakota State University, Hettinger, ND, USA \\ Email: *shana.forster@ndsu.edu
}

How to cite this paper: Forster, S.M., Ransom, J.K., Manthey, F.A., Rickertsen, J.R. and Mehring, G.H. (2017) Planting Date, Seeding Rate, and Cultivar Impact Agronomic Traits and Semolina of Durum Wheat. American Journal of Plant Sciences, 8, 2040-2055.

https://doi.org/10.4236/ajps.2017.89137

Received: July 3, 2017

Accepted: August 1, 2017

Published: August 4, 2017

Copyright $\odot 2017$ by authors and Scientific Research Publishing Inc. This work is licensed under the Creative Commons Attribution International License (CC BY 4.0).

http://creativecommons.org/licenses/by/4.0/

(c) (i) Open Access

\begin{abstract}
Durum wheat (Triticum durum Desf.) is a market class of wheat subject to price discounts in the marketplace if quality standards are not met. This study was conducted in order to determine how certain agronomic practices might impact durum wheat quality. The effects of planting date (PD), cultivar, and seeding rate on agronomic and semolina quality traits were investigated in field trials conducted near Hettinger and Minot, ND in 2014 and 2015. The interaction of PD and cultivar was significant for many of the traits evaluated. There was a significant PD X cultivar interaction or PD and cultivar effect for yield in all environments. Planting date X cultivar interacted for test weight at all environments. In general, a delay in PD resulted in a significant decrease in yield and test weight for all cultivars. However, Carpio yielded more than other cultivars in high yielding environments while the yield and test weight of Joppa was more adversely affected by delays in PD. Seeding rate did not have a consistent effect on any agronomic or quality trait. Protein content, kernel yellow pigment content, falling number (FN), and vitreous kernels were more dependent on cultivar, regardless of PD and environment. Semolina extraction, gluten index (GI), and wet gluten (WG) values tended to decrease with a delay in PD. These data continue to support cultivar selection as a critical component for obtaining high-yielding, high-quality durum wheat. However, PD and environment can impact certain agronomic and end-use traits, regardless of cultivar grown.
\end{abstract}

\section{Keywords}

Durum Wheat, Durum Quality, Planting Date, Seeding Rate, Semolina, Grain Protein 


\section{Introduction}

Durum wheat is a market class of wheat commonly grown in North Dakota with an average yield of $2700 \mathrm{~kg} \cdot \mathrm{ha}^{-1}$ [1]. Recently, durum wheat production in ND has declined due to competition for acres with hard red spring wheat (HRSW) (Triticum aestivum L.) which is generally less vulnerable to quality discounts. Producers, seed companies, grain buyers, grain millers, the pasta industry, and consumers evaluate durum wheat quality from different perspectives, but it is primarily grown for producing high-quality pasta [2]. Many production and environmental factors impact the quality of harvested durum wheat. Optimal planting date and selection of cultivars with favorable stress responses are agronomic management factors that can maximize durum wheat yield and quality [3].

Durum wheat grades are determined by the Federal Grain Inspection Service (FGIS) and the USDA Grain Inspection, Packers, and Stockyards Administration. Grades are important to the final market price and determined based on quality factors with subclasses within grades of durum wheat marketed based on the percentage of vitreous kernels. The majority of the 2014 durum wheat crop was US subclass grade amber durum (AD), while the 2015 crop was US grade 1 hard amber durum (HAD) [4] [5]. Essentially, HAD has a minimum test weight of $772 \mathrm{~kg} \cdot \mathrm{m}^{-3}$, less than $2 \%$ damaged kernels, and has a maximum limit of $0.4 \%$ foreign material, $3 \%$ broken kernels and defects, and $75 \%$ or more hard vitreous kernels [5]. Disease and mishandling of grain can cause damaged and broken kernels which can lower test weight. Grain kernels are considered hard vitreous because of high protein content and the absence of proteins that interact with starch granules [6].

The ability of a producer to maximize yield is an economic concern. One factor for producing high-quality durum wheat is cultivar grown [7]. Planting date and seeding rate of durum wheat can vary widely based on individual producers and environmental conditions. These choices also might impact the quality of harvested grain due to the environmental conditions during grain filling and harvest and are somewhat dependent on PD [8].

Breeding programs in the U.S. and Canada have as primary objectives the identification of cultivars with higher yield potential, better disease resistance profiles, and better end-use quality [9] [10] [11]. Unfortunately, durum wheat quality in recent years in ND has been regularly impacted by Fusarium head blight (FHB or scab) caused by Fusarium graminearum Schwabe [12] and most of the quality discounts associated with FHB are due to the presence of a pathogen-produced mycotoxin in the grain called deoxynivalinol (DON). Fungicide applications are essential due to limited genetic resistance in current durum wheat cultivars to FHB [13] [14] and are only partially effective in reducing DON levels when the FHB pressure is high.

Yield response due to N-P-fertilization was significantly higher for early and medium seeding dates than for the late seeding date for hard red spring and 
durum wheat [15]. Additionally, the seeding date X N-P-fertilization interaction was significant and indicated a decreasing response to fertilization with delayed planting. Seeding date did not significantly impact grain protein or test weight of durum wheat. Additionally, durum wheat yield in India was greatest at normal seeding dates and with increasing $\mathrm{N}$ and irrigation [16]. Flour characteristics such as grain protein content, $B$-carotene content, and sedimentation value were highest for the latest planting date. A genotype $\mathrm{X} \mathrm{N}$ input interaction was observed for several characteristics of early sown durum wheat and was also present in the optimum and late PD for grain yield [8].

Seeding rate trials to determine the optimum rate to maximize yield have been previously conducted in ND. However, many of these trials were conducted with cultivars no longer grown. Based on data, early PDs with seeding rates between 84 and $100 \mathrm{~kg} \cdot \mathrm{ha}^{-1}$ optimized grain yield and quality [17]. Yield of hard red spring and durum wheat was maximized at 247 plants $\mathrm{m}^{-2}$, but only when yield potential was greater than the 1970s average yield of $2350 \mathrm{~kg} \cdot \mathrm{ha}^{-1}$ [18]. More recently, test weight and protein were not impacted by a change in seeding rate across locations in north eastern ND [19]. A seeding rate of at least $141 \mathrm{~kg} \cdot \mathrm{ha}^{-1}$ viable seeds was suggested to optimize yield. Seeding rate could impact grain yield by increasing the number of spikes per area. Post-heading $\mathrm{N}$ accumulation and $\mathrm{N}$ remobilization were highest at a seeding rate of 400 seeds $\mathrm{m}^{-2}$ [20]. Seeding rate had a significant effect on HRSW yield in Canada [21]. Increasing yield was a function of more spikes produced due to more plants established; the tillering ability of a cultivar did not compensate for inadequate plant stands. Additionally, 12 HRSW cultivars evaluated for optimal seeding rate in eastern ND and $\mathrm{MN}$ found that when averaged across environments the highest yield was obtained at 350 seeds $\mathrm{m}^{-2}$, and subsequent regression analysis found that the predicted optimum rate to be 360 seeds $\mathrm{m}^{-2}$ [22].

Durum wheat genotypes responded differently to planting date and $\mathrm{N}$ rate when grown at three planting dates in California, USA, but no genotype consistently ranked the best across PDs [23]. Planting date also impacted semolina and pasta quality due to environmental changes during grain filling. Increased protein content observed in later sown durum wheat was suggested as a reason for increased dough strength [24]. These authors also observed a decrease in GI when planting was delayed and proposed that temperatures higher than $30^{\circ} \mathrm{C}$ during grain filling might affect the gluten polymerization process. In a similar study, GI increased as temperatures rose to $30^{\circ} \mathrm{C}$ and then decreased under higher temperatures [25]. In addition, spaghetti cooked firmness and protein content were positively correlated, but independent of planting date. As a result of this study, these researchers suggested that later PD might be a way of increasing pasta cooking quality by increasing overall protein.

The research reported herein was conducted in order to determine how PD, cultivar, and seeding rate impact agronomic traits and semolina and will enable recommendations to be developed which will aid durum wheat producers. 


\section{Materials and Methods}

\subsection{Growing Conditions and Plant Materials}

Experiments were conducted in 2014 and 2105 near Hettinger $\left(46^{\circ} 00^{\prime} 40^{\prime \prime} \mathrm{N}\right.$, $\left.102^{\circ} 38^{\prime} 40^{\prime \prime} \mathrm{W}\right)$ and Minot $\left(48^{\circ} 10^{\prime} 55^{\prime \prime} \mathrm{N}, 101^{\circ} 17^{\prime} 46^{\prime \prime} \mathrm{W}\right)$, ND. The soil types at each location were a Shambo- and an Aastad-loam in Hettinger and Minot, respectively [26]. Experiments at both locations were seeded directly into the stubble from the previous year using a no-till plot seeder. In Minot, the previous crops were flax (Linum usitatissimum L.) and field pea (Pisum sativum L.) in 2014 and 2015, respectively. The previous crops in Hettinger were HRSW and lentil (Lens culinaris Medik) in 2014 and 2015, respectively. Experimental units were 10.7 $\mathrm{m}^{-2}(1.6 \mathrm{~m}$ wide $\times 6.7 \mathrm{~m}$ long $)$ and $11.6 \mathrm{~m}^{-2}(1.52 \times 7.6 \mathrm{~m})$ in Hettinger and Minot, respectively. Row spacing was $17.8 \mathrm{~cm}$ at both locations. All plots were maintained using best management practices using appropriate pest control practices for the region [7] and fertilized with N-P based on yield potential and soil test results listed in Table 1. All soil tests were conducted by the North Dakota State University (NDSU) Soil Testing Laboratory, Fargo, ND using approved and standard practices. A plot combine harvester with a $1.52 \mathrm{~m}$ wide head was utilized to harvest durum wheat in experimental units when grain moisture was near 13\% (Table 2).

The durum wheat cultivars, Carpio, Divide, and Joppa, evaluated in this experiment were developed by the NDSU durum wheat breeding program and released by the North Dakota Agricultural Experiment Station [10] [27] [28]. Divide was selected because it was grown on the largest area in ND for the previous seven consecutive years, accounting for 30\% of the acreage in 2015 [4]. Joppa and Carpio were selected based on their recent availability to ND producers and excellent end-use qualities. Seeding rates were determined based on current recommendations and producer practices [7].

Table 1. Soil factors measured prior to planting near hettinger and minot, ND in 2014 and 2015.

\begin{tabular}{cccccccccc}
\hline Environment & $\begin{array}{c}\text { Depth } \\
(\mathrm{cm})\end{array}$ & $\begin{array}{c}\mathrm{NO}_{3}-\mathrm{N} \\
\left(\mathrm{kg} \cdot \mathrm{ha}^{-1}\right)\end{array}$ & $\begin{array}{c}\mathrm{P} \\
\left(\mathrm{mg} \cdot \mathrm{kg}^{-1}\right)\end{array}$ & $\begin{array}{c}\mathrm{K} \\
\left(\mathrm{mg} \cdot \mathrm{kg}^{-1}\right)\end{array}$ & $\mathrm{pH}$ & $\begin{array}{c}\mathrm{OM} \\
(\%)\end{array}$ & $\begin{array}{c}\mathrm{Zn} \\
\left(\mathrm{mg} \cdot \mathrm{kg}^{-1}\right)\end{array}$ & $\begin{array}{c}\mathrm{Fe} \\
\left(\mathrm{mg} \cdot \mathrm{kg}^{-1}\right)\end{array}$ & $\begin{array}{c}\mathrm{Cl} \\
\left(\mathrm{mg} \cdot \mathrm{kg}^{-1}\right)\end{array}$ \\
\hline Hettinger & & & & & & & & & \\
2014 & $0-15$ & 34 & 33 & 345 & 6.0 & 2.8 & 0.88 & 75 & 3.5 \\
& $15-30$ & 27 & 7 & 175 & 7.3 & 2.4 & 0.32 & 25 & 9.0 \\
2015 & $0-15$ & 81 & 35 & 625 & 6.4 & 3.8 & 2.17 & 64 & 10.6 \\
& $15-30$ & 34 & 8 & 200 & 7.0 & 2.6 & 0.37 & 24 & 13.9 \\
\hline \multirow{2}{*}{ Minot } & & & & & & & & & \\
2014 & $0-15$ & 138 & 18 & 365 & 4.4 & 3.2 & 0.74 & 86 & 32.9 \\
& $15-30$ & 28 & 2 & 167 & 6.0 & 2.2 & 0.20 & 35 & 59.1 \\
2015 & $0-15$ & 88 & 13 & 310 & 5.9 & 3.7 & 1.23 & 62 & 26.3 \\
& $15-30$ & 20 & 4 & 410 & 6.7 & 2.4 & 0.39 & 32 & 22.2 \\
\hline
\end{tabular}


Table 2. Planting and harvest date of durum wheat near Hettinger and Minot, ND in 2014 and 2015.

\begin{tabular}{|c|c|c|c|c|c|}
\hline \multirow{2}{*}{ Environment } & Planting Date & Harvest Date & Environment & Planting Date & Harvest Date \\
\hline & \multicolumn{2}{|c|}{2014} & & \multicolumn{2}{|c|}{2015} \\
\hline \multirow[t]{4}{*}{ Hettinger } & May 2 & Aug. 28 & Hettinger & April 14 & Aug. 17 \\
\hline & May 15 & Sept. 4 & & April 29 & Aug. 17 \\
\hline & May 27 & Sept. 8 & & May 13 & Aug. 20 \\
\hline & June 9 & Oct. 14 & & May 27 & Sept. 4 \\
\hline \multirow[t]{4}{*}{ Minot } & May 14 & Sept. 9 & Minot & April 29 & Aug. 28 \\
\hline & May 27 & Sept. 16 & & May 11 & Aug. 28 \\
\hline & June 4 & Oct. 9 & & May 26 & Sept. 12 \\
\hline & June 17 & Oct. 24 & & June 9 & Sept. 12 \\
\hline
\end{tabular}

\subsection{Data Collection}

Plant height was determined by averaging two measurements per plot. The plant height was calculated based on the distance from the soil to the top of the plant's spike at physiological maturity excluding awns. Grain yield from harvested field plots was recorded on a clean-grain basis corrected to $13 \%$ seed moisture content. Test weight was measured using methodology specified by the American Association of Cereal Chemists International (AACC) [29] (Approved Method 55 - 10.01). Protein content of whole durum wheat samples was determined using a Perten Instruments DA7200 NIR analyzer (Springfield, IL). Thousand kernel weight was determined by calculating the number of kernels in a $10 \mathrm{~g}$ sample and converting data to the weight of 1000 kernels. Percent large kernels were determined by sieving a $100 \mathrm{~g}$ sample and determining the weight of kernels that remained on the top of a $2.92 \mathrm{~mm}$ sieve [30]. Vitreous kernel was the percentage of 100 kernels cut with a farinator having a vitreous endosperm. The AACC International procedures were used for yellow pigment color (pigment) content (Method 14 - 50.01), polyphenol oxidase (PPO) (Method 22 - 85.01), milling semolina extraction/yield (Method 26 - 50.01), semolinaprotein content (Method 46 - 30.01), gluten index (GI) and wet gluten (WG) (Method 38 12.02), falling number (FN) (Method 56 - 81.03), and ash content (Method 08 01.01) [29].

\subsection{Experimental Design and Statistical Analysis}

The experimental design was a randomized complete block with a split-plot arrangement.

Treatments were replicated four times. Whole plots consisted of PD (see Table 2 for actual dates). Durum wheat cultivars (Carpio, Divide, and Joppa) and seeding rates $\left(222,297\right.$, and 371 viable seeds $\left.\mathrm{m}^{-2}\right)$ comprised subplots and were arranged in a two-way factorial arrangement.

Analysis of variance was conducted for each of the variables measured. 
Combined analyses of variance across environments were calculated for all variables. Data for each environment were analyzed using PROC GLM procedure of SAS software [31]. Planting date, cultivar, and seeding rate were considered fixed effects. Replications and years were considered random effects. Mean comparisons using $F$-protected LSDs were made to separate PD, cultivar, and seeding rate where $\mathrm{F}$-tests indicated significant differences existed $(P<0.05)$. LSDs for the combined analyses were calculated based on the methodology previously described [32].

\section{Results}

The average daily temperature for the 2014 growing season (May through October) was $69 \%$ and $97 \%$ of the long-term average in Hettinger and Minot, respectively [33]. Alternatively, the average daily temperature for the 2015 growing season (April through September) in Hettinger and Minot was slightly above the long-term average at $103 \%$ and $106 \%$ of normal, respectively. Precipitation totals during the 6-month growing season were above the long term average at both locations for both years. In 2014, the months of June and August had the most precipitation at both locations. In 2015, the months of May and June had the most precipitation at both locations.

When environments were combined, PD had a significant impact on yield (Table 3). With each delay in PD, yield decreased by 329, 504, and $672 \mathrm{~kg} \cdot \mathrm{ha}^{-1}$ across all cultivars, seeding rates, and environments, respectively. Yield was the only agronomic factor evaluated that significantly differed based on PD across environments. Differences among cultivars for traits such as test weight, protein content, seed size, and vitreous kernel were detected across locations. Overall, the seeding rates evaluated had limited impacts on the agronomic and quality traits evaluated across locations. The seeding rate of 297 plants $\mathrm{m}^{-2}$ resulted in the highest average yield. The yield advantage compared to the next highest yielding seeding rate of 222 plants $\mathrm{m}^{-2}$ was approximately a $2 \%$ increase and not significant. In general, the G X E interaction was significant at all locations for most traits evaluated. Based on the differences among PD, emergence date, heading date, and harvest date, the growing environments were quite different; however, some general trends were observed. Pooled correlation values were calculated based on all environments (Table 4).

All cultivars experienced a yield reduction when PD was delayed in all environments. The yield reduction for Joppa at PD 4 was much greater than Carpio or Divide in all environments (data not shown). This would indicate when producers are faced with a delay in planting due to weather conditions; selecting Carpio or Divide would be a better choice than Joppa, if maximizing yield is the primary objective. An interaction between PD and cultivar in all environments was observed for test weight. Industry standard test weight of $772 \mathrm{~kg} \cdot \mathrm{m}^{-3}$ was achieved in Joppa, and Carpio tended to have higher test weights than Divide for the later PDs across environments. However, the test weight of Divide was similar 
Table 3. Soil Impact of main effects on planting date, cultivar, and seeding rate on agronomictraits ${ }^{\mathrm{a}}$ associated with durum wheat near Hettinger and Minot, ND in 2014 and 2015.

\begin{tabular}{|c|c|c|c|c|c|c|c|c|}
\hline & $\begin{array}{l}\mathrm{Ht} \\
(\mathrm{cm})\end{array}$ & $\begin{array}{c}\text { TW } \\
\left(\mathrm{kg} \cdot \mathrm{m}^{-3}\right)\end{array}$ & $\begin{array}{c}\text { Yield } \\
\left(\mathrm{kg} \cdot \mathrm{ha}^{-1}\right)\end{array}$ & $\begin{array}{c}\text { Pro } \\
\left(\mathrm{g} \cdot \mathrm{kg}^{-1}\right)\end{array}$ & $\begin{array}{c}\text { Kwt } \\
\left(\mathrm{g} 1000^{-1}\right)\end{array}$ & $\begin{array}{l}\text { FN } \\
(s)\end{array}$ & $\begin{array}{c}\text { Large } \\
(\%)\end{array}$ & $\begin{array}{l}\text { Vit } \\
(\%)\end{array}$ \\
\hline \multicolumn{9}{|c|}{ Planting Date } \\
\hline 1 & 84 & 770 & 4340 & 137 & 44.1 & 460 & 70.4 & 67.8 \\
\hline 2 & 90 & 768 & 4011 & 135 & 44.1 & 440 & 68.6 & 73.8 \\
\hline 3 & 88 & 749 & 3507 & 136 & 40.1 & 417 & 59.1 & 65.4 \\
\hline 4 & 83 & 726 & 2835 & 148 & 42.6 & 385 & 63.5 & 71.5 \\
\hline $\mathrm{LSD}^{\mathrm{z}}$ & NS & NS & 73 & NS & NS & NS & NS & NS \\
\hline \multicolumn{9}{|c|}{ Cultivar } \\
\hline Carpio & 86 & 755 & 3722 & 137 & 43.8 & 437 & 72.8 & 66.9 \\
\hline Divide & 87 & 750 & 3554 & 143 & 42.3 & 444 & 65.0 & 68.9 \\
\hline Joppa & 86 & 754 & 3742 & 137 & 42.0 & 369 & 58.4 & 73.1 \\
\hline $\mathrm{LSD}^{\mathrm{z}}$ & NS & 2 & NS & 1 & 1.0 & NS & 4.6 & 5.0 \\
\hline \multicolumn{9}{|c|}{ Seeding Rate } \\
\hline \multicolumn{9}{|c|}{ seeds $\mathrm{m}^{-2}$} \\
\hline 222 & 86 & 753 & 3642 & 139 & 43.2 & 425 & 66.7 & 69.7 \\
\hline 297 & 86 & 754 & 3722 & 139 & 42.6 & 426 & 65.3 & 70.2 \\
\hline 371 & 86 & 753 & 3662 & 139 & 42.3 & 426 & 64.2 & 69.0 \\
\hline $\mathrm{LSD}^{\mathrm{z}}$ & NS & NS & NS & NS & 0.9 & NS & 2.2 & NS \\
\hline $\mathrm{CV}$ & 4.9 & 1.5 & 8.6 & 4.3 & 4.4 & 7.3 & 7.1 & 9.4 \\
\hline
\end{tabular}

${ }^{\mathrm{a}} \mathrm{Ht}=$ plant height, $\mathrm{TW}=$ test weight, Pro $=$ protein, $\mathrm{Kwt}=$ weight of 1000 seeds, $\mathrm{FN}=$ falling number, Large $=$ kernels remaining on a $2.92 \mathrm{~mm}$ sieve, Vit $=$ vitreous kernel, $\mathrm{NS}=$ not significant at $P=0.05$ level. ${ }^{2}$ LSD was calculated to compare all levels of the main effect according to Fisher's Protected LSD $(P \leq 0.05)$; $\mathrm{CV}=$ coefficient of variation.

or higher than Carpio and Joppa at the early PDs, but was subject to a larger decrease than these two cultivars with a delay in PD. For example, Carpio and Joppa had higher test weights of 761 and $759 \mathrm{~kg} \cdot \mathrm{m}^{-3}$, respectively when the seeding rate was 222 seeds $\mathrm{m}^{-2}$ in this environment. Based on regional quality reports [4], test weight averages for both 2014 and 2015 were not subject to discounts.

All locations had a similar trend for cultivar rankings, with Divide having the highest protein content, regardless of planting date. Divide also was the lowest yielding cultivar. No significant relationship existed between protein content and grain yield $(\mathrm{r}=-0.16, \mathrm{n}=144)$ (Table 4$)$. The general trend was an increase in grain protein content with each delay in PD. The protein content from all cultivars at PD 4 resulted in the highest grain protein content in most environments. Generally, the FN scores were much higher in 2015 than in 2014 for all PDs and cultivars. There was no significant relationship between FN and percentage 
Table 4. Pooled correlation values for agronomic and quality traits of trials conducted near Hettinger and Minot, ND in 2014 and $2015(\mathrm{n}=144)$.

\begin{tabular}{|c|c|c|c|c|c|c|c|c|c|c|c|c|c|c|}
\hline & TW & Yield & Pro & Pig & PPO & Kwt & Large & FN & Vit & Ash & Sem & Semp & GI & WG \\
\hline $\mathrm{Ht}$ & $0.21^{\mathrm{NS}}$ & $0.07^{\mathrm{NS}}$ & $-0.06^{\mathrm{NS}}$ & $0.54^{* * *}$ & -0.05 & $-0.11^{\mathrm{NS}}$ & $-0.28^{\star *}$ & $0.16^{\mathrm{NS}}$ & $-0.60^{\star * *}$ & $-0.70^{* * *}$ & $0.70^{* * *}$ & $0.40^{* * *}$ & $0.48^{\star * *}$ & $0.02^{\mathrm{NS}}$ \\
\hline TW & - & $0.07^{\mathrm{NS}}$ & $-0.07^{\mathrm{NS}}$ & $0.20^{\mathrm{NS}}$ & 0.14 & $0.19^{\mathrm{NS}}$ & $0.00^{\mathrm{NS}}$ & $-0.05^{\mathrm{NS}}$ & $-0.33^{\star *}$ & $-0.26^{*}$ & $0.32^{* *}$ & $0.04^{\mathrm{NS}}$ & $0.36^{* * *}$ & $-0.12^{\mathrm{NS}}$ \\
\hline Yield & - & - & $-0.16^{\mathrm{NS}}$ & $-0.60^{\star * *}$ & -0.07 & $0.03^{\mathrm{NS}}$ & $0.09^{\mathrm{NS}}$ & $0.18^{\mathrm{NS}}$ & $0.58^{\star * *}$ & $0.62^{\star * \star}$ & $-0.54^{\star * *}$ & $-0.55^{\star * *}$ & $-0.48^{\star \star *}$ & $-0.01^{\mathrm{NS}}$ \\
\hline Pro & - & - & - & $-0.31^{\star *}$ & -0.37 & $-0.56^{\star * *}$ & $-0.30^{* *}$ & $-0.19^{\mathrm{NS}}$ & $0.03^{\mathrm{NS}}$ & $0.16^{\mathrm{NS}}$ & $-0.32^{\star *}$ & $0.65^{\star * *}$ & $-0.27^{\star \star}$ & $0.53^{* * *}$ \\
\hline Pig & - & - & - & - & 0.56 & $0.25^{\star}$ & $0.24^{*}$ & $-0.08^{\mathrm{NS}}$ & $-0.80^{\star \star *}$ & $-0.60^{* * *}$ & $0.66^{* * *}$ & $0.41^{\star * *}$ & $0.78^{\star * *}$ & $-0.45^{\star * *}$ \\
\hline PPO & - & - & - & - & - & $0.71^{\star * *}$ & $0.88^{* * *}$ & $-0.01^{\mathrm{NS}}$ & $-0.55^{\star * *}$ & $-0.13^{\mathrm{NS}}$ & $0.16^{\mathrm{NS}}$ & $-0.03^{\mathrm{NS}}$ & $0.50^{\star * \star}$ & $-0.77^{\star * *}$ \\
\hline Kwt & - & - & - & - & - & - & $0.81^{\star * *}$ & $0.06^{\mathrm{NS}}$ & $-0.27^{\star *}$ & $-0.14^{\mathrm{NS}}$ & $0.13^{\mathrm{NS}}$ & $-0.39^{\star * *}$ & $0.34^{\star * *}$ & $-0.64^{\star * \star}$ \\
\hline Large & - & - & - & - & - & - & - & $0.09^{\mathrm{NS}}$ & $-0.30^{\star *}$ & $0.05^{\mathrm{NS}}$ & $-0.05^{\mathrm{NS}}$ & $-0.20^{\mathrm{NS}}$ & $0.21^{\mathrm{NS}}$ & $-0.66^{\star * *}$ \\
\hline FN & - & - & - & - & - & - & - & - & $0.07^{\mathrm{NS}}$ & $-0.19^{\mathrm{NS}}$ & $0.40^{* * *}$ & $-0.10^{\mathrm{NS}}$ & $0.13^{\mathrm{NS}}$ & $-0.09^{\mathrm{NS}}$ \\
\hline Vit & - & - & - & - & - & - & - & - & - & $0.61^{* * *}$ & $-0.62^{\star * *}$ & $-0.53^{\star \star *}$ & $-0.69^{\star * \star}$ & $0.39^{* * *}$ \\
\hline Ash & - & - & - & - & - & - & - & - & - & - & $-0.72^{\star * *}$ & $-0.29^{* *}$ & $-0.65^{\star \star *}$ & $0.14^{\mathrm{NS}}$ \\
\hline Sem & - & - & - & - & - & - & - & - & - & - & - & $0.26^{*}$ & $0.72^{\star * *}$ & $-0.21^{\mathrm{NS}}$ \\
\hline Semp & - & - & - & - & - & - & - & - & - & - & - & - & $0.23^{*}$ & $0.37^{\star * *}$ \\
\hline GI & - & - & - & - & - & - & - & - & - & - & - & - & - & $-0.62^{* * *}$ \\
\hline
\end{tabular}

${ }^{*}, * *,{ }^{* * *}$ is significant at $P<0.05,0.01$, and 0.001 level, respectively, ${ }^{\mathrm{NS}}=$ not significant at $P=0.05$ level. $\mathrm{Ht}=$ plant height, TW $=$ test weight, Pro $=$ protein, $\mathrm{Pig}=$ yellow pigment, $\mathrm{PPO}=$ polyphenol oxidase, $\mathrm{Kwt}=$ weight of 1000 seeds, $\mathrm{FN}=$ falling number, Large $=$ kernels remaining on a $2.92 \mathrm{~mm}$ sieve, $\mathrm{Vit}=$ vitreous kernel, Sem = semolina, Semp = semolina protein, GI = gluten index, $\mathrm{WG}=$ wet gluten .

vitreous kernel $(\mathrm{r}=0.07, \mathrm{n}=144)$. Grain produced from all PDs and cultivars in the 2014 environments had sufficient levels of vitreous kernels to be graded HAD, except for PD4 in Hettinger. Total precipitation received and average dew points for the seven days preceding harvest for each environment were much lower in 2014 compared to 2015 (data not shown). The mean percent vitreous kernels for 2014 and 2015 were 91 and 74\%, respectively, and were similar to regional quality reports [4].

Additional characteristics important to pasta processors and end-users were largely not influenced by $\mathrm{PD}$, seeding rate, or environment and were specific to the cultivar evaluated (Table 5). Kernel yellow pigment values were consistent for each cultivar, with Divide having the lowest pigment values and with Carpio having the highest values in most environments. Previous research has identified a strong genotypic effect on semolina yellowness, while brown index or semolina brightness were mainly determined by the environment [34]. Brown index and semolina brightness were not determined in the current study. Significant differences among cultivars were identified in each environment for polyphenol oxidase (PPO) activity. Carpio had significantly higher PPO activity compared to Divide or Joppa in all environments. Cultivar was not significant for kernel ash content for any environment. Semolina yield significantly increased from planting date 1 to 3 , but tended to decrease in planting date 4 in 2014. In 2015, no trend existed for semolina yield based on PD (data not shown). 
Table 5. Impact of main effects of planting date, cultivar, and seeding rate on quality traits $^{\mathrm{a}}$ associated with durum wheat near Hettinger and Minot, ND in 2014 and 2015.

\begin{tabular}{|c|c|c|c|c|c|c|c|}
\hline & $\begin{array}{c}\text { Pig } \\
(\mathrm{ppm})\end{array}$ & $\begin{array}{c}\text { PPO } \\
\left(\Delta \mathrm{OD}_{475} / \mathrm{hr} / 5 \text { kernels }\right)\end{array}$ & $\begin{array}{l}\text { Ash } \\
(\%)\end{array}$ & $\begin{array}{c}\text { Sem } \\
(\%)\end{array}$ & $\begin{array}{c}\text { Semp } \\
\left(\mathrm{g} \cdot \mathrm{kg}^{-1}\right)\end{array}$ & $\begin{array}{c}\text { GI } \\
(\%)\end{array}$ & $\begin{array}{l}\text { WG } \\
\text { (\%) }\end{array}$ \\
\hline \multicolumn{8}{|c|}{ Planting Date } \\
\hline 1 & 9.1 & 0.16 & 1.6 & 55.1 & 12.0 & 81.4 & 31.7 \\
\hline 2 & 9.3 & 0.18 & 1.6 & 54.8 & 12.0 & 89.7 & 30.6 \\
\hline 3 & 9.7 & 0.16 & 1.6 & 53.0 & 12.3 & 90.8 & 31.3 \\
\hline 4 & 9.5 & 0.18 & 1.6 & 54.6 & 13.3 & 86.7 & 32.9 \\
\hline $\mathrm{LSD}^{\mathrm{z}}$ & NS & NS & NS & NS & NS & NS & NS \\
\hline \multicolumn{8}{|l|}{ Cultivar } \\
\hline Carpio & 10.1 & 0.38 & 1.6 & 54.4 & 12.2 & 95.0 & 29.5 \\
\hline Divide & 8.4 & 0.06 & 1.6 & 54.2 & 12.5 & 78.9 & 33.3 \\
\hline Joppa & 9.7 & 0.01 & 1.6 & 54.5 & 12.6 & 87.4 & 32.0 \\
\hline $\mathrm{LSD}^{\mathrm{z}}$ & 0.5 & 0.02 & NS & NS & NS & 3.4 & 0.5 \\
\hline \multicolumn{8}{|c|}{$\begin{array}{l}\text { Seeding Rate } \\
\left(\text { seeds } \mathrm{m}^{-2} \text { ) }\right.\end{array}$} \\
\hline 222 & 9.4 & 0.17 & 1.6 & 54.4 & 12.2 & 86.8 & 31.8 \\
\hline 297 & 9.4 & 0.17 & 1.6 & 54.4 & 12.8 & 87.4 & 31.6 \\
\hline 371 & 9.4 & 0.17 & 1.6 & 54.3 & 12.2 & 87.2 & 31.5 \\
\hline $\mathrm{LSD}^{\mathrm{z}}$ & NS & NS & NS & NS & NS & NS & NS \\
\hline $\mathrm{CV}$ & 3.6 & 29.0 & 4.6 & 4.3 & 4.3 & 5.2 & 6.8 \\
\hline
\end{tabular}

${ }^{\mathrm{a}} \mathrm{Pig}=$ yellow pigment, $\mathrm{PPO}=$ polyphenol oxidase, $\mathrm{Sem}=$ semolina extracted, Semp $=$ semolina extracted protein, $\mathrm{GI}=$ gluten index, and WG $=$ wet gluten, $\mathrm{NS}=$ not significant at $p=0.05$ level. ${ }^{\mathrm{z}} \mathrm{LSD}$ was calculated to compare all levels of the main effect according to Fisher's Protected LSD ( $p \leq 0.05)$; CV = coefficient of variation.

Significant differences among cultivars were identified for semolina yield in 2014 environments with the percent semolina extracted from Joppa and Carpio more than Divide (Table 5). The percentage of semolina yield extracted was much higher in 2015 than 2014, but no significant differences among cultivars were observed, but are consistent with long-term trials [4] [10]. Semolina yield was inversely related to grain protein content $(\mathrm{r}=-0.32, \mathrm{n}=144)$. A strong relationship between WG and protein also existed $(\mathrm{r}=0.53, \mathrm{n}=144)$. Divide had the highest protein and WG at all PDs in the 2015 environments. In 2014, Joppa had the highest WG even though Divide had higher grain protein. Wet gluten percent was similar across all environments (data not shown).

\section{Discussion}

These data indicate that even in different environmental conditions, planting durum wheat early is the best option for maximizing yield regardless of cultivar or environment. The impact of $\mathrm{G} \times \mathrm{E}$ interactions on traits such as protein content 
and gluten quality [2] and yellow pigment, grain yield, brown index [34] in durum wheat have been documented. Cultivar and PD and are each important factors when it comes to maximizing grain yield of durum wheat. The yield of cultivars followed the trend of Joppa > Carpio > Divide and was consistent with regional and variety trial results conducted from 2008 to 2014 [10]. Joppa was the highest yielding cultivar. It is possible, that when Joppa and Carpio are planted in a high yielding environment, Carpio could yield more than Joppa. Planting of durum wheat in ND can range from the late April to early June, depending on the individual producer and weather conditions. These data indicate that durum producers can maximize yields by planting as soon as conditions are favorable.

Hard red spring and durum wheat response to PD and NP-fertilization after fallow was evaluated and found that grain yield did not differ significantly between the first and second PD, but were significantly lower for the last PD [15]. Early seeding of both wheat classes was important to maximize response to N-P-fertilization and a decrease in response to fertilization was observed with delayed seeding. All PDs in the current study were fertilized when planted. The delay in yield response to PD in the current study also could have been affected by a decrease in the response to fertilization. Additionally, the durum wheat cultivars evaluated are considered daylength-sensitive. The delay in PD could result in less vegetative growth and utilization of soil nutrients prior to reproductive stages which could result in a decrease of yield.

Previous studies conducted in ND showed a yield response to seeding rate [18] [19]; however, the durum wheat cultivars evaluated in these studies are no longer grown. In addition, those trials were conducted in the Langdon, ND area and far northwest ND near Williston, ND and were seeded at different seeding rates compared to those examined in the current experiments. In the current trial, the seeding rates evaluated were 222,297 , and 371 viable seeds $\mathrm{m}^{-2}$. Significant differences could have been more difficult to detect in the current trial compared to previous trials because the differences in seeding rates were not as extreme and did not include a seeding rate lower than standard practices. The seeding rates in these experiments represent seeding rates commonly utilized by ND durum wheat producers [7].

The effect of different seeding rates $\left(200,250\right.$, and 400 seeds $\left.\mathrm{m}^{-2}\right)$ on grain yield and $\mathrm{N}$ uptake of durum wheat cultivars Creso, Simento, and Svevo evaluated in Italy found that the seeding rate $\mathrm{X}$ cultivar interactions were not significant for any of traits evaluated [20]. Accordingly, in temperate climates such as the United Kingdom, an optimal seeding rate was between 300 and 450 seed $\mathrm{m}^{-2}$ for winter wheat [35]. In HRSW, no significant interactions for seeding rate $\times$ cultivar or tillage $\times$ seeding rate $\times$ cultivar were identified for yield near Dickinson, ND [36].

Diverse cultivars of HRSW differed in their response to seeding rate, when grown in ND and MN due to the diverse genetic background of the cultivars [22]. The durum wheat cultivars evaluated in the current study represent a narrow 
genetic background compared to the HRSW cultivars. Environment played a significant role in determining the optimum seeding rate of HRSW and found that in high yielding environments the optimum seeding rate was less than in lower yielding environments. In the current studies, no significant PD X seeding rate interaction for yield was observed suggesting that when PD is delayed, a higher seeding rate might not be beneficial. Therefore, based on these data, the seeding rates of the durum wheat cultivars evaluated could be lowered to a seeding rate of 222 seeds $\mathrm{m}^{-2}$ to minimize the costs associated with the extra seed at the higher seeding rates while not adversely affecting yield.

Protein content in durum wheat is related to genotype, environmental conditions, and G X E interactions and could be the cause of the differences observed among environments. When planting date was delayed, mean grain weight declined, but mean grain protein increased from $10.7 \%$ to $14.7 \%$ [24]. Previous research did not find a significant effect of PD on protein content or test weight [15], while delay in PD resulted in the highest grain protein, $\beta$-carotene, and sedimentation values and suggested that high temperatures and low humidity during grain filling could also result in increased grain protein content [16].

Breeding for high protein cultivars is complicated by the inverse relationship between protein and grain yield [11] [14]. A negative significant relationship between grain yield and protein in durum wheat was identified based on correlation coefficients ranging from -0.59 to -0.66 , depending on PD and $\mathrm{N}$ input [8]. In the current study, a negative relationship between protein content and yield occurred across cultivars $(\mathrm{r}=-0.16, \mathrm{n}=144)$. Based on regional durum nursery testing and NDSU durum variety trials conducted from 2008 to 2014, Divide had a higher average grain protein concentration of $146 \mathrm{~g} \cdot \mathrm{kg}^{-1}$ compared to Carpio and Joppa at 144 and $140 \mathrm{~g} \cdot \mathrm{kg}^{-1}$, respectively [10]. Average protein values for the ND growing region in 2014 and 2015 were 131 and $136 \mathrm{~g} \cdot \mathrm{kg}^{-1}$ at $12 \%$ moisture, respectively [4]. In the current research, Divide had an average grain protein content of $143 \mathrm{~g} \cdot \mathrm{kg}^{-1}$, compared to Carpio and Joppa that both had an average of $137 \mathrm{~g} \cdot \mathrm{kg}^{-1}$.

Environmental conditions can lead to preharvest sprouting (PHS); however, based on precipitation and average dew points, environmental conditions were not the sole basis for the low FN observe during PD 4. Based on the regional durum wheat quality report [4], the average FN for 2014 and 2015 were 276 and 414 secs, respectively. Carpio and Divide had significantly higher FN than Joppa in long term trials [10]. Similar results were found in this research indicating that regardless of PD and environment, the cultivar Joppa might be more prone to PHS than the other two cultivars. The cutting date (date the spike was removed from stem) $\times$ cultivar interaction was not significant for FN, however, the effect ofcutting date could have been limited by the procedures used to store grain prior to evaluation [37]. The cutting dates used in the previous study were only 10 days apart while in the current study, harvest dates differed by up to five weeks. 
Vitreousness is a quality characteristic of durum wheat that affects the yield of semolina during milling. Processors require vitreous kernels in order to maintain high levels of semolina. When the durum wheat grain heads are subject to high relative humidity one to three days prior to harvest, a reduction in vitreous kernels can result [38]. Subclasses of durum wheat grading are based on a separate marketing factor of percentage vitreous kernels. Vitreous kernels can be influenced by $G \times E$ interactions and the interaction of $G \times E$ was significant on metabolite composition and durum wheat grain quality [39]. Carpio had slightly higher kernel vitreousness compared to Divide and Joppa across 30 site years [10], but in the current research Joppa had the highest average percent vitreous kernels of 73\%. Carpio and Divide had 67 and 69\% vitreous kernels, respectively.

Joppa consistently had the highest percent vitreous kernels, regardless of PD for all environments which would be an option for durum wheat producers if maintaining a high percentage of vitreous kernels is the main objective. Specific rainfall events at grain fill and physiological maturity might have impacted the percent vitreous kernels. Most likely, the environmental conditions just prior to harvest had the most effect on vitreous kernels. Unfortunately, this also suggests that $\mathrm{PD}$, cultivar grown, and seeding rate are relatively ineffective ways available to growers to maintain vitreous kernels, as environment plays such a dominant role. Percentage of vitreous kernels is often determined by N. For example, more $\mathrm{N}$ was needed in order to achieve a given percentage of vitreous kernels as the proportion of $\mathrm{N}$ applied at tillering was increased [40]. However, early harvest associated with an early PD may favor higher percentage of vitreous kernels.

Semolina extraction in the current studies was not as high as reported from the regional reports. The regional report consists of a much larger sample size and may be the reason for the differences observed. Additionally, the type of mill used for semolina extraction was different for this research than that of the regional report. The current study used a Brabender Quadromat Jr. Mill (South Hackensack, NJ) for semolina extraction which tends to have lower semolina yields than semolina extraction from Buhler MLU 202 configured with two Miag purifiers (F. Manthey, personal communication).

As PD was delayed, GI decreased and research suggested that temperatures greater than $30^{\circ} \mathrm{C}$ at grain filling resulted in a negative effect on gluten polymerization [24]. Differences in PD would result in different temperatures during grain filling; however, no trends between PD 1 and 4 were observed. A similar trend in a reduction in GI was seen for Joppa in 2015; however, GI values for Joppa in 2014 were not as impacted by PD and were similar to the Carpio GI values except for PD 1 in Minot. The GI values observed in the current research based on cultivar were consistent with previous reports [10] where Carpio and Joppa had significantly higher GI than Divide. A similar trend in higher WG values in 2015 was observed in the current research. In an effort to identify the relationship between gluten protein and quality, the gliadin-to-gluten ratio of the durum wheat cultivars Trigumurruand Svevo was evaluated and found that the Mediterranean environment significantly affected this ratio, but could not 
explain the variation in temperature from the different planting times [25].

\section{Conclusion}

Planting date and cultivar interactions had the greatest impact on the agronomic and quality traits evaluated. The performance of individual cultivars evaluated in this study was similar to previous yield and quality reports generated from the same growing region. In the highest yielding environments, Carpio yield was superior to that of Divide and Joppa. When planting was delayed; however, the yield of Joppa tended to decrease more than either Carpio or Divide. Carpio or Divide should be grown when planting is delayed. These data also indicate that through a range of environmental conditions, planting durum wheat early is the best option for maximizing yield regardless of cultivar or environment. Current selection and evaluation practices in durum wheat breeding programs should develop cultivars for specific environments and also for different PDs. The interaction of PD X cultivar had a significant effect on test weight; early PDs resulted in test weight values at or above the US grade 1 minimum standard for all three cultivars. Environment significantly impacted percent vitreous kernels. All cultivars evaluated were subject to loss of vitreousness caused by precipitation and humidity around maturity and harvest. No specific planting date, cultivar, or experimental location consistently produced durum that would be graded as HAD. Characteristics such as protein content, FN, kernel yellow pigment content, and GI were more dependent on cultivar than environment or PD. Many of the end-use data generated in this research are consistent with regional and multiyear evaluations. Neither PD nor seeding rate impacted most quality traits evaluated.

\section{Acknowledgements}

We wish to thank the ND Wheat Commission for financial support of this project.

\section{References}

[1] National Agricultural Statistics Service (2014) Crops Data. https://www.nass.usda.gov

[2] Troccoli, A., Borrelli, G.M., De Viat, P., Fares, C. and Di Fonzo, N. (2000) Durum Wheat Quality: A Multidisciplinary Concept. Journal of Cereal Science, 32, 99-113. https://doi.org/10.1006/jcrs.2000.0322

[3] Pfeiffer, W.H., Sayre, K.D. and Reynolds, M.P. (2000) Enhancing Genetic Grain Yield Potential and Yield Stability on Durum Wheat. In: Royo, C. Nachit, M., Difonzo, N. and Araus, J.L., Eds., Durum Wheat Improvement in the Mediterranean Region: New Challenges, CIHEAM, Paris, Zaragoza, 83-93.

[4] North Dakota Wheat Commission (2015) U.S. Durum Wheat Regional Quality Report. North Dakota Wheat Commission, Bismarck.

[5] United States Department of Agriculture (2013) Grain Grading Procedures. https://www.gipsa.usda.gov/fgis/standards/810wheat.pdf 
[6] Dexter, J.E., Williams, P.C., Edwards, N.M. and Martin D.G. (1988) The Relationship Between Durum Wheat Vitreousness Kernel Hardness and Processing Quality. Journal of Cereal Science, 7, 169-181. https://doi.org/10.1016/S0733-5210(88)80018-3

[7] Ransom, J.K., et al. (2017) Field Guide to Sustainable Production of Quality Durum Wheat in North Dakota. A1825. North Dakota State University Extension Service, Fargo.

[8] Ehdaie, B. and Waines, J.G. (2001) Sowing Date and Nitrogen Rate Effects on Dry Matter and Nitrogen Partitioning in Bread and Durum Wheat. Field Crops Research, 73, 47-61. https://doi.org/10.1016/S0378-4290(01)00181-2

[9] Clarke, J.M., Marchylo, B.A., Kovacs, M.I.P., Noll, J.S., McCaig, T.N. and Howes, N.K. (1998) Breeding Durum Wheat for Pasta Quality in Canada. Euphytica, 100, 163-170. https://doi.org/10.1023/A:1018313603344

[10] Elias, E.M. and Manthey, F.A. (2016) Registration of "Joppa" Durum Wheat. Journal of Plant Registrations, 10, 139-144. https://doi.org/10.3198/jpr2015.11.0071crc

[11] Royo, C., Elias, E. and Manthey, F. (2009) Durum Wheat Breeding. In: Carena, M.J., Ed., Cereals, Springer Science, New York, 199-226.

https://doi.org/10.1007/978-0-387-72297-9_6

[12] McMullen, M., Zhong, S. and Neate, S. (2008) Fusarium Head Blight (Scab) of Small Grains. North Dakota State University Extension Service, Fargo, 804 p.

[13] Buerstmayr, M., Huber, K., Heckman, J., Steiner, B., Nelson, J.C. and Buerstmayr, H. (2012) Mapping of QTL for Fusarium Head Blight Resistance and Morphological and Developmental Traits in Three Backcross Populations Derived from Triticum dicoccum x Triticum durum. Theoretical and Applied Genetics, 125, 1751-1765. https://doi.org/10.1007/s00122-012-1951-2

[14] Clarke, J.M., Clarke, F.R. and Pozniak, C.J. (2010) Forty-Six Years of Genetic Improvement in Canadian Durum Wheat Varieties. Canadian Journal of Plant Science, 90, 791-801. https://doi.org/10.4141/cjps10091

[15] Black, A.L. and Siddoway, F.H. (1977) Hard Red and Durum Spring Wheat Responses to Seeding Date and NP-Fertilization on Fallow. Agronomy Journal, 69, 885888. https://doi.org/10.2134/agronj1977.00021962006900050041x

[16] Singh, A.K. and Jain, G.L. (2000) Effect of Sowing Time and Nitrogen on Grain Yield and Quality of Durum Wheat (Triticum durum). Indian Journal of Agricultural Sciences, 70, 532-533.

[17] Quick, J.S. and Wilkins, H.D. (1975) Durum...a North Dakota Specialty. North Dakota State University Extension Service, Fargo.

[18] Riveland, N.R., French, E.W., Hoag, B.K. and Conlon, T.J. (1979) The Effect of Seeding Rate on Spring Wheat Yields in Western North Dakota-An Update. North Dakota Farm Research, 37, 15-20.

[19] Hanson, B.K. and Lukach, J.R. (1992) Semi-Dwarf Durum Response to Planting Rate in Northeastern North Dakota. North Dakota Farm Research, 49, 6-12.

[20] Arduini, I., Masoni, A., Ercoli, L. and Mariotti, M. (2006) Grain Yield, and Dry Matter and Nitrogen Accumulation and Remobilization in Durum Wheat as Affected by Variety and Seeding Rate. European Journal of Agronomy, 25, 309-318. https://doi.org/10.1016/j.eja.2006.06.009

[21] Lafond, G.P. and Derksen, D.A. (1996) Row Spacing and Seeding Rate Effects on Wheat and Barley under a Conventional Fallow Management System. Canadian Journal of Plant Sciences, 76, 791-793. https://doi.org/10.4141/cjps96-132 
[22] Mehring, G.H. (2016) Determining Optimum Seeding Rates for Diverse Hard Red Spring Wheat (Triticum aestivum) Cultivars. Ph.D. Thesis, North Dakota State University, Fargo.

[23] Ehdaie, B., Shakiba, M.R. and Waines, J.G. (2001) Sowing Date and Nitrogen Input Influence Nitrogen-Use Efficiency in Spring Bread and Durum Wheat Cultivars. Journal of Plant Nutrition, 24, 899-919. https://doi.org/10.1081/PLN-100103781

[24] Motzo, R., Fois, S. and Giunta, F. (2007) Protein Content and Gluten Quality of Durum Wheat (Triticum turgidum subsp. durum) as Affected by Sowing Dates. Journal of Science and Food Agriculture, 87, 1480-1488. https://doi.org/10.1002/jsfa.2855

[25] Fois, S., Schlichting, L., Marchylo, B., Dexter, J., Motzo, R. and Giunta, F. (2011) Environmental Conditions Affect Semolina Quality in Durum Wheat (Triticum turgidum ssp. durum L.) Cultivars with Different Gluten Strength and Gluten Protein Composition. Journal of Science and Food Agriculture, 91, 2664-2667. https://doi.org/10.1002/jsfa.4509

[26] United States Department of Agriculture (2016) Natural Resources Conservation Service Web Soil Survey.

http://websoilsurvey.nrcs.usda.gov/app/WebSoilSurvey.aspx

[27] Elias, E.M., Manthey, F.A. and AbuHammad, A. (2015) Registration of 'Carpio' Durum Wheat. Journal of Plant Registrations, 9, 78. https://doi.org/10.3198/jpr2014.05.0030crc

[28] Elias, E.M. and Manthey, F.A. (2007) Registration of 'Divide' Durum Wheat. Journal of Plant Registrations, 1, 7-8. https://doi.org/10.3198/jpr2006.05.0281crc

[29] AACC, International (2000) Approved Methods of the American Association of Cereal Chemists. 10th Edition, AACC, St. Paul, MN.

[30] Shuey, W.C. (1960) A Wheat Sizing Technique for Predicting Flour Milling Yield. Cereal Science Today, 5, 71-72.

[31] SAS Institute (2010) The SAS System for Windows. Release 9.3, SAS Institute, Cary, NC.

[32] Carmer, S.G., Nyquist, W.E. and Walker, W.M. (1989) Least Significant Differences for Combined Analyses of Experiments with Two- or Three-Factor Treatment Designs. Agronomy Journal, 81, 665-672.

https://doi.org/10.2134/agronj1989.00021962008100040021x

[33] North Dakota Agricultural Weather Network (NDAWN) (2016) ND Weather Data. North Dakota State University, Fargo.

[34] Schulthess, A., Matus, I. and Schwember, A.R. (2013) Genotypic and Environmental Factors and Their Interactions Determine Semolina Color of Elite Genotypes of Durum Wheat (Triticum turgidum L. var. durum) Grown in Different Environments of Chile. Field Crops Research, 149, 234-244. https://doi.org/10.1016/j.fcr.2013.05.001

[35] Ghaffari, A., Cook, H.F. and Lee, H.C. (2001) Simulating Winter Wheat Yields under Temperate Conditions: Exploring Different Management Scenarios. European Journal of Agronomy, 15, 231-240. https://doi.org/10.1016/S1161-0301(01)00111-3

[36] Carr, P.M., Horsley, R.D. and Poland, W.W. (2003) Tillage and Seeding Rate Effects in Wheat Cultivars: I. Grain Production. Crop Science, 43, 202-209. https://doi.org/10.2135/cropsci2003.2020

[37] Gelin, J.R., Elias, E.M., Manthey, F.A. and Grant, L. (2007) Study of the Relationship between Sprouting Score and Sprout Damage in Durum Wheat (Triticum turgidum L. var. durum). Cereal Research Communication, 35, 53-61. https://doi.org/10.1556/CRC.35.2007.1.7 
[38] Sandhu, K., Manthey, F.A. and Elias, E.M. (2009) High Relative Humidity Affects Vitreousness of Durum Wheat [Triticum turgidum L. var. durum (Desf)]. Cereal Research Communication, 37, 269-275. https://doi.org/10.1556/CRC.37.2009.2.15

[39] Beleggia, R., Platani, C., Nigor, F., De Vita, P., Cattivelli, L. and Papa, R. (2013) Effect of Genotype, Environment, and Genotype-by-Environment Interaction on Metabolite Profiling in Durum Wheat (Triticum durum Desf.) Grain. Journal of Cereal Science, 57, 183-192. https://doi.org/10.1016/j.jcs.2012.09.004

[40] Anderson, W.K. (1985) Grain Yield Responses of Barley and Durum Wheat to Split $\mathrm{N}$ Applications under Rainfed Conditions in a Mediterranean Environment. Field Crops Research, 12, 191-202. https://doi.org/10.1016/0378-4290(85)90068-1

\section{Abbreviations}

AD: Amber Durum; FN: Falling Number; GI: Gluten Index; HAD: Hard Amber Durum; PD: Planting Date; PHS: Preharvest Sprouting; PPO: Polyphenol Oxidase; WG: Wet Gluten

Submit or recommend next manuscript to SCIRP and we will provide best service for you:

Accepting pre-submission inquiries through Email, Facebook, LinkedIn, Twitter, etc. A wide selection of journals (inclusive of 9 subjects, more than 200 journals)

Providing 24-hour high-quality service

User-friendly online submission system

Fair and swift peer-review system

Efficient typesetting and proofreading procedure

Display of the result of downloads and visits, as well as the number of cited articles

Maximum dissemination of your research work

Submit your manuscript at: http://papersubmission.scirp.org/

Or contact ajps@scirp.org 